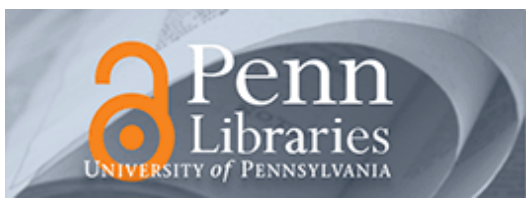

University of Pennsylvania ScholarlyCommons

Wharton Pension Research Council Working Papers

Wharton Pension Research Council

$1-1-2003$

\title{
Defined Benefit Pension Plan Liabilities and International Asset Allocation
}

Tongxuan (Stella) Yang

The Wharton School, University of Pennsylvania, TONGXUAN@WHARTON.UPENN.EDU

Follow this and additional works at: https://repository.upenn.edu/prc_papers

Part of the Economics Commons

Yang, Tongxuan (Stella), "Defined Benefit Pension Plan Liabilities and International Asset Allocation" (2003). Wharton Pension Research Council Working Papers. 421.

https://repository.upenn.edu/prc_papers/421

This paper is posted at ScholarlyCommons. https://repository.upenn.edu/prc_papers/421

For more information, please contact repository@pobox.upenn.edu. 


\title{
Defined Benefit Pension Plan Liabilities and International Asset Allocation
}

\begin{abstract}
Despite the integration of international capital markets and the relaxation of capital controls, U.S. defined benefit pension plans do not sufficiently diversify their assets across international holdings. In this paper, we explore whether incorporating liabilities in the asset allocation decision can help explain pension plans' home bias. We find that incorporating pension liabilities proves not to explain pension plan home bias in the case when returns are nominal. Furthermore, when we focus on real returns, incorporating pension plan liabilities makes the home bias puzzle worse. The fact remains that U.S. defined benefit pension plans could benefit substantially from more international investment.
\end{abstract}

\section{Disciplines}

Economics 


\title{
Defined Benefit Pension Plan Liabilities and International Asset Allocation
}

\author{
Tongxuan Yang
}

PRC WP 2003-5

\section{Pension Research Council Working Paper}

\author{
Pension Research Council \\ The Wharton School, University of Pennsylvania \\ 3641 Locust Walk, 304 CPC \\ Philadelphia, PA 19104-6218 \\ Tel: 215.898.7620 • Fax: 215.898.0310 \\ Email: prc@wharton.upenn.edu \\ http://prc.wharton.upenn.edu/prc/prc.html
}

Pension Research Council Working Papers are intended to make research findings available to other researchers in preliminary form, to encourage discussion and suggestions for revision before final publication. Opinions are solely those of the authors.

Research support is acknowledged from the Steven H. Sandell Grant program of the U.S. Social Security Administration (SSA) and the Michigan Retirement Research Center (MRRC). The Opinions and conclusions are solely those of the author and should not be construed as representing the opinions or policy of SSA or MRRC. The author appreciates valuable suggestions and comments from James Barber, Steven Boyce, J. David Cummins, Jeremy Gold, David Gustafson, Richard Herring, Urban Jermann, Marie-Eve Lachance, Karen Lewis, Richard Marston, David McCarthy, Olivia S. Mitchell, James Moore, Alex Muermann, Arun S. Muralidhar, Kurtay Ogunc, and Jane Pacelli. Any remaining errors are the author's responsibility.

(C)2003 Pension Research Council of the Wharton School of the University of Pennsylvania. All Rights Reserved. 


\title{
Defined Benefit Pension Plan Liabilities and International Asset Allocation
}

\author{
Tongxuan Yang
}

\begin{abstract}
$\underline{\text { Abstract }}$
Despite the integration of international capital markets and the relaxation of capital controls, U.S. defined benefit pension plans do not sufficiently diversify their assets across international holdings. In this paper, we explore whether incorporating liabilities in the asset allocation decision can help explain pension plans' home bias. We find that incorporating pension liabilities proves not to explain pension plan home bias in the case when returns are nominal. Furthermore, when we focus on real returns, incorporating pension plan liabilities makes the home bias puzzle worse. The fact remains that U.S. defined benefit pension plans could benefit substantially from more international investment.
\end{abstract}




\title{
Defined Benefit Pension Plan Liabilities and International Asset Allocation
}

\author{
Tongxuan Yang
}

Whether pension funds efficiently allocate assets and hedge risk is a key concern of plan sponsors, plan participants, and the whole economy. For decades, economists have recognized the benefit of international diversification. But compared with the international level of asset allocation deserved from standard portfolio theory (Levy and Sarnat 1970 for example), the portfolios of institutional investors are far from optimal. Specifically, U.S. defined benefit (DB) plans hold too little in international assets and too much in domestic assets, reflecting the socalled equity "home bias" puzzle.

As distinct from mutual funds, DB plans have to meet their funding requirements. Therefore, only maximizing total assets is not enough for a DB pension plan; instead, DB plans should also take into account their liability patterns when determining asset allocations. We are interested in the question of whether pension liabilities should influence pension international asset allocation decisions, and whether including measures of liabilities might be part of the explanation for pension plan home bias.

In this paper, we employ a mean-variance approach to explore how DB pension plan international asset allocation patterns might change, after taking pension liabilities into account. We apply our model to a hypothetical U.S. DB pension plan. Our empirical analysis shows that taking account of pension liabilities in DB investment decisions does not explain the observed home bias. Consequently we conclude that home bias in U.S. DB pension plans is still a puzzle, and such plans could benefit substantially from holding more international assets. 
In what follows, we first show the benefit of international diversification of pension funds and illustrate the home bias puzzle of DB pension plans. Next, we develop a simple meanvariance model to explore the impact of liabilities on pension fund international asset allocation. Then we provide an empirical analysis of a hypothetical pension plan, and provide some concluding comments.

\section{Home Bias and DB Pension Plan Liability}

When foreign and domestic market returns are not perfectly correlated, domestic investors may benefit from international investment. Levy and Sarnat (1970) and Solnik (1988, 1998) have shown the advantages of international portfolio diversification. As an institutional investor, a defined benefit pension plan must invest its assets in the capital market to back up retirement promises. As explained by Davis (2002), pension plans may benefit from international risk sharing for several reasons. First, international investment can broaden a pension plan's efficient frontier, rewarding investors with a higher return for the same risk, or with lower risk for the same return. Second, foreign investment may offer inflation protection, as exchange rates depreciate during periods of inflation when domestic asset returns are poor. Third, especially in developing countries where the economy is volatile or where production is relatively concentrated, international investment can help pension plans diversify risk, offer more investment vehicles, and curtail shortfall risk.

With the integration of international capital markets and the relaxation of capital controls, institutional investors' holdings of foreign securities are increasing, as illustrated in Table 1. For instance, U.S. DB pension fund holdings of foreign securities increased from 0.7 percent in 1980 to 11.8 percent in 1998. However, compared with Lewis' (1995) recommendation that U.S. investors should hold over 40 percent of their assets internationally, actual investments are 
strongly home-biased. French and Poterba (1991), Cooper and Kaplanis (1994), Tesar and Werner (1995) also find that home bias is strong for U.S. investors.

\section{Table 1 here}

Several explanations for investor home bias have been suggested in the international finance literature. ${ }^{1}$ Nevertheless, research in the past two decades suggests that none of these explanations is fully convincing. One rationale is that home equity may help hedge domestic risks such as inflation and non-tradable wealth. But Cooper and Kaplanis (1994) find that inflation hedge motives cannot explain home bias, and indeed sometimes the hedge motives are in the opposite direction than would be expected. Furthermore, Baxter and Jermann (1997) find that "international diversification puzzle" is deepened once the implications of non-tradable human capital are considered for portfolio composition. A second rationale for home bias is that foreign returns implicit in equities of domestic firms having overseas operations could mean that so-called "domestic" firms actually are substantially diversified internationally. Although this argument sounds plausible, Jacqillat and Solnik (1978) show that stocks of multinationals usually move quite closely with their respective national market indexes. A third rationale offered is that government restrictions, transaction costs, and tax policies might imply that diversification costs could exceed gains. For example, Lewis (1999) suggests that government restrictions and information costs might explain why emerging markets are biased away from holding equities in emerging market. On the other hand, this argument cannot explain the home bias puzzle for developed countries that do not face such restrictions. A fourth possible rationale is that information asymmetry generates hurdles for international investment, and "familiarity breeds investment" as argued by Huberman (2001). Yet it is unclear whether domestic investors actually have better information about domestic equities; for instance, Froot, O'Connell and 
Seasholes (2001), Froot and Ramadorai (2001), and Seasholes (2000) report that international investors appear no less informed than domestics. All of these studies focus on investors in general; there has been little research on why pension funds in particular might display home bias.

DB pension plans differ from other institutional investors because of the key role played by pension liabilities. DB plan liabilities refer to a plan sponsor's long-term promise to pay an eventual benefit. After the enacting of Employee Retirement Income Security Act (ERISA), pension sponsors must guarantee the solvency and funding status of their DB plans. Therefore DB pension plan managers should consider not only their asset returns but also their plans' liabilities. Ignoring liabilities in pension asset allocation may lead to improper investment decisions.

A DB pension plan's liability is affected by two categories of factors, namely demographic, and economic. The demographic factors include mortality, termination, disability, and retirement, all of which will influence plan liabilities. Economic factors such as inflation, productivity increase, and capital market performance, also affect plan liabilities through wage growth or discount rates. In this paper, the main focus is on the effect of wage growth rates and discount rates on plan liabilities and asset allocation, while holding the demographic factors constant. Since wage growth rates and discount rates may be correlated with asset returns, our hypothesis is that consideration of liability in pension asset allocation may explain part of DB pension plan home bias. 


\section{Pension Asset and Liability Management with International Assets in the Portfolio}

To assess the role of home bias in pension investment, we adopt and extend the meanvariance model of Lewis (1999). First, the optimal asset allocation under the asset-only approach is calculated. Second, we extend the model to include DB pension liabilities. Finally, asset allocations under the asset-only approach and the asset/liability approach are compared, to determine whether there may be home bias introduced by consideration of pension liabilities.

Pension Asset Allocation under the Asset-Only Approach. For expositional simplicity and following Lewis (1999), we suppose there are only two assets, domestic assets and international assets. ${ }^{2}$ The asset allocation problem for the institutional investor is to invest the plan's wealth in these two asset classes. The objective of the investor is to maximize the expected return of his portfolio while penalizing the volatility of the return:

$$
\underset{\mathrm{x}_{\mathrm{d}}, \mathrm{x}_{\mathrm{i}}}{\operatorname{Max}} E\left(\widetilde{R}_{A}\right)-\frac{\lambda}{2} \operatorname{Var}\left(\widetilde{R}_{A}\right)
$$

where $R_{A}$ is the total return of the portfolio, and

$$
\widetilde{R}_{A}=x_{d} \widetilde{R}_{d}+x_{i} \widetilde{R}_{i}
$$

where

$R_{d}$ is actual return on domestic assets;

$R_{i}$ is actual return on international assets;

$\mu_{d}, \sigma_{d}$ are the mean and standard deviation on domestic equity returns;

$\mu_{i}, \sigma_{i}$ are the mean and standard deviation on international equity returns;

$\sigma_{d i}$ is covariance between domestic and international equity returns;

$x_{d}$ is the proportion of total assets invested in domestic equities; 
$x_{i}$ is the proportion of total assets invested in international equities; and

$\lambda$ is the risk aversion of institutional investors.

The expected return is $E\left(\widetilde{R}_{A}\right)=x_{d} \mu_{d}+x_{i} \mu_{i}$, and the variance of the portfolio is $\operatorname{Var}\left(\widetilde{R}_{A}\right)=x_{d}^{2} \sigma_{d}^{2}+x_{i}^{2} \sigma_{i}^{2}+2 x_{d} x_{i} \sigma_{d i}$. After taking into account the restriction $x_{d}+x_{i}=1$ and solving the F.O.C, the optimal international asset allocation should be:

$$
x_{i}=\frac{\left(\mu_{i}-\mu_{d}\right)}{\lambda \operatorname{Var}\left(\widetilde{R}_{i}-\widetilde{R}_{d}\right)}+\frac{\sigma_{d}{ }^{2}-\sigma_{d i}}{\operatorname{Var}\left(\widetilde{R}_{i}-\widetilde{R}_{d}\right)}
$$

If $\mu_{i}-\mu_{d}>0$, the portfolio share of international asset holdings will increase with the expected international equity premium $\mu_{i}-\mu_{d}$, decrease with the risk aversion factor $\lambda$, and decrease with the variance of the actual return difference, $\operatorname{Var}\left(\widetilde{R}_{i}-\widetilde{R}_{d}\right)$. Also the portfolio share of international investments will increase with the second term on the right hand side, which is the portfolio share that minimizes the variance of the wealth portfolio.

Pension Asset Allocation under Asset/Liability Approach. Maximizing asset returns alone might not be a sufficient objective for DB pension plans, if plan managers have multiple objectives. ${ }^{3}$ One important issue is that DB pension plans have to meet solvency and funding requirements. Most DB pension plans try to maintain or better their solvency and funding status, while limiting the increase and variability of future contributions. Sharpe and Tint (1990) propose that a pension plan's optimal asset allocation can be derived using an asset/liability approach, by maximizing the expected surplus under risk penalty. Grinold and Meese (2000) recently employed the Sharpe and Tint (1990) approach to derive an optimal international asset allocation pattern for institutional investors. However, they did not undertake empirical research to compare how their results might differ from those produced by the traditional asset-only approach. In the present paper, we adopt and revise the asset/liability approach of Sharpe and 
Tint (1990) to evaluate the empirical effect of liabilities on DB plan international asset allocation.

In our hypothetical DB pension plan, we represent the active participant pool assuming the active worker's average year of service $\bar{T}_{0}$, and the illustrative retired participant pool assuming that the retiree's average benefit payment is $B_{r}$. For expositional simplicity, we assume there is no demographic change in the plan, so all retired and active participants will survive to next year for sure. In a final wage plan, the promised benefit is:

$$
\widetilde{B}=k * \widetilde{W} * T
$$

where $k$ is a constant proportion of pay, such as $2 \%$; $W$ is the final pay level of plan participants; and $T$ represents the worker's year of service. Suppose the total contribution of the pension plan is a certain percentage, $m$, of wage. Then the annual contribution to the plan is:

$$
\widetilde{C}=m^{*} \tilde{W}
$$

In our model, the main concern of the pension manager is the next year's surplus. This amount can be expressed relative to today's asset value, i.e. $\widetilde{S}_{1} / A_{0}$. According to Sharp and Tint (1990), relating future surplus to today's asset value is a natural extension of asset-only practice, where the dimension of measured risk tolerance is maintained. A DB plan manager will maximize $\widetilde{S}_{1} / A_{0}$, while penalizing its risk. The decision variables are the asset proportion invested in domestic and international equities, $x_{d}$ and $x_{i}$ :

$$
\underset{\mathrm{x}_{\mathrm{d}}, \mathrm{x}_{\mathrm{i}}}{\operatorname{Max}} E\left(\frac{\widetilde{S_{1}}}{A_{0}}\right)-\frac{\lambda}{2} \operatorname{Var}\left(\frac{\widetilde{S_{1}}}{A_{0}}\right) .
$$

Then next year's surplus is $\widetilde{S}_{1}=\widetilde{A}_{1}-\widetilde{L}_{1}$, where $\widetilde{A}_{1}, \widetilde{L}_{1}$ are next year's asset and liability levels. In this paper, subscript 1 means next year, and 0 means today. All information as of today is 
known, such as equity returns, pension assets, liabilities, contributions, and benefits paid. For the next year, only the benefit payment $B_{r}$ is known, while other variables are stochastic.

We then suppose that each year, the plan receives one contribution and makes one benefit payment at the same time. As of that day, we can rewrite $\widetilde{S}_{1}$ as the total market value of investments plus next year's contribution, minus the benefit payments and next year's liability: ${ }^{4}$

$$
\widetilde{S}_{1}=A_{0}\left(1+\widetilde{R}_{A}\right)+\widetilde{C}_{1}-\widetilde{L}_{1}
$$

Next year's surplus relative to today's asset is:

$$
\begin{aligned}
\frac{\widetilde{S}_{1}}{A_{0}} & =\left(1+\widetilde{R}_{A}\right)+m \frac{W_{0}}{A_{0}} \frac{\widetilde{W}_{1}}{W_{0}}-\frac{L_{0}}{A_{0}} \frac{\widetilde{L}_{1}}{L_{0}} \\
& =\left(1+\widetilde{R}_{A}\right)+m \frac{W_{0}}{A_{0}}\left(1+\widetilde{R}_{W}\right)-\frac{L_{0}}{A_{0}}\left(1+\widetilde{R}_{L}\right),
\end{aligned}
$$

where $\widetilde{R}_{W}$ and $\widetilde{R}_{L}$ are the growth rate of wages and liabilities. Plugging (4) into (3), rearranging terms and removing those with no uncertainty, over which the asset allocation decision has no influence (see details in Appendix 1), the maximization problem becomes:

$$
\underset{\mathrm{x}_{\mathrm{d}}, \mathrm{x}_{\mathrm{i}}}{\operatorname{Max}} E\left(\widetilde{R}_{A}\right)-\frac{\lambda}{2} \operatorname{Var}\left(\widetilde{R}_{A}\right)-\lambda m \frac{W_{0}}{A_{0}} \operatorname{cov}\left(\widetilde{R}_{A}, \widetilde{R}_{W}\right)+\lambda \frac{L_{0}}{A_{0}} \operatorname{cov}\left(\widetilde{R}_{A}, \widetilde{R}_{L}\right)
$$

The first two terms in (5) are the same as in (1) which ignored pension liabilities. Therefore, the difference in the two models lies in the last two terms. Focusing on the last term, we define $\lambda \frac{L_{0}}{A_{0}} \operatorname{cov}\left(\widetilde{R}_{A}, \widetilde{R}_{L}\right)$ as the "asset liability hedging credit", consistent with Sharpe and Tint (1990). This term may have a hedging effect on liability increases if the covariance is positive. Therefore, a DB pension plan should alter its asset allocation to take advantage of such hedge effects, in order to realize the objective of maximizing pension surplus. Since $R_{A}=x_{d} \widetilde{R}_{d}+x_{i} \widetilde{R}_{i}$, the covariance term $\operatorname{cov}\left(\widetilde{R}_{A}, \widetilde{R}_{L}\right)$ can be divided into: 


$$
\operatorname{cov}\left(\widetilde{R}_{A}, \widetilde{R}_{L}\right)=\operatorname{Cov}\left(x_{d} \widetilde{R}_{d}+x_{i} \widetilde{R}_{i}, \widetilde{R}_{L}\right)=x_{d} \operatorname{Cov}\left(\widetilde{R}_{d}, \widetilde{R}_{L}\right)+x_{i} \operatorname{Cov}\left(\widetilde{R}_{i}, \widetilde{R}_{L}\right)
$$

When the covariance $\operatorname{Cov}\left(\widetilde{R}_{d}, \widetilde{R}_{L}\right)$ or $\operatorname{Cov}\left(\widetilde{R}_{i}, \widetilde{R}_{L}\right)$ is positive, the corresponding assets will help hedge liability increases. The greater a fund manager's risk aversion, $\lambda$, the larger the asset liability hedging credit; the lower today's funding ratio, $\frac{A_{0}}{L_{0}}$, the more valuable the hedging credit. On the other hand, if the covariance term were zero (or negative), then the corresponding asset would have no beneficial (or even a negative) hedging effect.

The third term in equation (5), $-\lambda m \frac{W_{0}}{A_{0}} \operatorname{cov}\left(\widetilde{R}_{A}, \widetilde{R}_{W}\right)$, comes from plan contributions. This term implies that wage growth rates may have a hedging effect on equity returns. If there is a negative relation between equity returns and wage growth rates, the hedge effect will be positive, i.e. the asset decrease in the pension fund due to bad investment performance could be offset by increased contributions from wage growth rate increases. The greater the fund manager's risk aversion, $\lambda$, and the higher the contribution ratio, the larger wage rate's hedging effect. But if the covariance is positive, the corresponding asset will have a negative hedging effect.

It is difficult to obtain time series data on pension fund liabilities, so we cannot calculate the required covariance terms directly. For this reason, we model the growth rate of liabilities and use some proxy variables for sensitivity analysis. In this paper, we use the Accumulated Benefit Obligation (ABO) to calculate pension liabilities. ABO represents the on-going plan's liability from the perspective of pension accounting, equaling the present value of accrued benefits. ${ }^{5}$ Today's ABO can be projected to next year with appropriate approximations. The following is a full year projection: ${ }^{6}$ 


$$
(A B O)_{1} \approx\left[(A B O)_{0}+h(A B O)_{0}\right](1+\widetilde{r})-E(B)_{1}
$$

where : $(A B O)_{0}$ refers to the accumulated benefit obligation for all plan members as of today;

$r$ is the discount rate used with $\mathrm{ABO}$;

$E(B)_{1}$ represents yearly expected benefit payments, equal to $B_{r}$ for retirees; and

$h$ is the fraction of the $\mathrm{ABO}$ accounting for service and salary increases.

For our representative active plan participant, the benefit accrued is expressed as $B=k W T$. The $h$ coefficient to $(A B O)_{0}$ can be determined as:

$$
h=\frac{B_{1}-B_{0}}{B_{0}}=\frac{k \widetilde{W}_{1} \bar{T}_{1}-k W_{0} \bar{T}_{0}}{k W_{0} \bar{T}_{0}}=\frac{k W_{0}\left(1+\widetilde{R}_{w}\right)\left(\bar{T}_{0}+1\right)-k W_{0} \bar{T}_{0}}{k W_{0} \bar{T}_{0}}=\widetilde{R}_{w}+\frac{1}{\bar{T}_{0}}\left(1+\widetilde{R}_{w}\right) .
$$

Hence, the liability growth rate, $\widetilde{R}_{L}$ can be expressed as:

$$
\widetilde{R}_{L}=\frac{(A B O)_{1}-(A B O)_{0}}{(A B O)_{0}}=\frac{1}{\overline{T_{0}}}+\left(1+\frac{1}{\overline{T_{0}}}\right)\left(\widetilde{R}_{W}+\widetilde{r}+\widetilde{R}_{W} \tilde{r}\right)-\frac{B_{r}}{L_{0}}
$$

The liability growth rate, $\widetilde{R}_{L}$ will depend on three stochastic terms: the wage growth rate, $\widetilde{R}_{W} ;$ the discount rate, $\widetilde{r}$; and the product of these two variables, $\widetilde{R}_{W} \widetilde{r}$. Therefore, when we substitute the expression of $\widetilde{R}_{L}$ into (5), we obtain the final maximization problem:

$$
\underset{x_{d}^{\prime}, x_{i}^{\prime}}{\operatorname{Eax}}\left\{\begin{array}{l}
E\left(\widetilde{R}_{A}\right)-\frac{\lambda}{2} \operatorname{Var}\left(\widetilde{R}_{A}\right)+\lambda\left[\frac{L_{0}}{A_{0}}\left(1+\frac{1}{\bar{T}}\right)-m \frac{W_{0}}{A_{0}}\right] \operatorname{cov}\left(\widetilde{R}_{A}, \widetilde{R}_{W}\right) \\
+\lambda \frac{L_{0}}{A_{0}}\left(1+\frac{1}{\bar{T}}\right) \operatorname{cov}\left(\widetilde{R}_{A}, \widetilde{r}\right)+\lambda \frac{L_{0}}{A_{0}}\left(1+\frac{1}{\bar{T}}\right) \operatorname{cov}\left(\widetilde{R}_{A}, \widetilde{R}_{W} \widetilde{r}\right)
\end{array}\right\} .
$$

The first two terms in (6) are the same as those in (1), where (1) is the maximization problem under the asset-only approach. The objective function (6) under our asset/liability management approach also includes three other terms. All these three terms depend on some common factors including risk aversion, $\lambda$, the reciprocal of funding ratio, $L_{0} / A_{0}$, and the 
average year of service, $\bar{T}$. Except for these common factors, each term also includes some unique factors. The third term in (6) depends on the contribution rate, $m$, the ratio of total wage over pension asset as of today, $W_{0} / A_{0}$, and the covariance between equity returns and wage growth rates. The fourth and last term in (6) also depends on the covariance between equity returns and discount rates, and the covariance between equity returns and the product of wage growth rates and discount rates respectively.

After solving the F.O.C. of (6), we have:

$$
x_{i}^{\prime}=\frac{\left(U_{i}-U_{d}\right)}{\lambda \operatorname{Var}\left(\widetilde{R}_{i}-\widetilde{R}_{d}\right)}+\frac{\sigma_{d}{ }^{2}-\sigma_{d i}}{\operatorname{Var}\left(\widetilde{R}_{i}-\widetilde{R}_{d}\right)},
$$

where,

$$
\begin{aligned}
U_{i}= & \mu_{i}+\lambda\left[\frac{L_{0}}{A_{0}}\left(1+\frac{1}{\bar{T}}\right)-m \frac{W_{0}}{A_{0}}\right] \operatorname{cov}\left(\widetilde{R}_{i}, \widetilde{R}_{W}\right) \\
& +\lambda \frac{L_{0}}{A_{0}}\left(1+\frac{1}{\bar{T}}\right) \operatorname{cov}\left(\widetilde{R}_{i}, \widetilde{r}\right)+\lambda \frac{L_{0}}{A_{0}}\left(1+\frac{1}{\bar{T}}\right) \operatorname{cov}\left(\widetilde{R}_{i}, \widetilde{R}_{W} \widetilde{r}\right) \\
U_{d}= & \mu_{d}+\lambda\left[\frac{L_{0}}{A_{0}}\left(1+\frac{1}{\bar{T}}\right)-m \frac{W_{0}}{A_{0}}\right] \operatorname{cov}\left(\widetilde{R}_{d}, \widetilde{R}_{W}\right) \\
& +\lambda \frac{L_{0}}{A_{0}}\left(1+\frac{1}{\bar{T}}\right) \operatorname{cov}\left(\widetilde{R}_{d}, \widetilde{r}\right)+\lambda \frac{L_{0}}{A_{0}}\left(1+\frac{1}{\bar{T}}\right) \operatorname{cov}\left(\widetilde{R}_{d}, \widetilde{R}_{W} \widetilde{r}\right)
\end{aligned}
$$

In equation (7), $x_{i}^{\prime}$ is the optimal asset proportion invested in international asset under the asset/liability management approach. We call $U_{i}$ in (8) the "liability-adjusted expected return on international equity" because it is the expected international equity return, $\mu_{i}$, adjusted by three pension liability terms. By the same token, $U_{d}$ is called the "liability-adjusted expected return on domestic equity". For $U_{i}$ and $U_{d}$, if the summation of the last three terms is positive, 
then the liability-adjusted expected return is greater than the actual expected return. Hence consideration of liability gives credit to the corresponding asset return, without affecting the variance and covariance of equity returns.

The only difference between $x_{i}^{\prime}$ in (7) and $x_{i}$ in (2) is the numerator of the first term, which is the difference between the liability-adjusted expected return instead of the expected return as in (2):

$$
\begin{aligned}
\left(U_{i}-U_{d}\right)-\left(\mu_{i}-\mu_{d}\right)=\lambda\left[\frac{L_{0}}{A_{0}}(1\right. & \left.\left.+\frac{1}{\bar{T}}\right)-m \frac{W_{0}}{A_{0}}\right]\left[\operatorname{cov}\left(\widetilde{R}_{i}, \widetilde{R}_{W}\right)-\operatorname{cov}\left(\widetilde{R}_{d}, \widetilde{R}_{W}\right)\right] \\
& +\lambda \frac{L_{0}}{A_{0}}\left(1+\frac{1}{\bar{T}}\right)\left[\operatorname{cov}\left(\widetilde{R}_{i}, \widetilde{r}\right)-\operatorname{cov}\left(\widetilde{R}_{d}, \widetilde{r}\right)\right] \\
& +\lambda \frac{L_{0}}{A_{0}}\left(1+\frac{1}{\bar{T}}\right)\left[\operatorname{cov}\left(\widetilde{R}_{i}, \widetilde{R}_{W} \widetilde{r}\right)-\operatorname{cov}\left(\widetilde{R}_{d}, \widetilde{R}_{W} \widetilde{r}\right)\right]
\end{aligned}
$$

If the right hand side of (9) is negative, (i.e. if some or all of the covariance differences are negative,) then $x_{i}^{\prime}<x_{i}$. In this case, pension plans should hold less international equities but more domestic equities when liabilities are incorporated in the pension asset allocation decision. ${ }^{7}$ Consequently, at least part of a DB plan's home bias might be attributable to the fact that liabilities are captured by the pension asset allocation decision. If the right hand side of (9) is zero, then considering pension liabilities does not influence pension asset allocations. This zero right hand side could result from three zero covariance differences, or from the offsetting of all three terms on the right hand side. If the right hand side of (9) is positive, then the optimal investment in international equity under asset/liability management should be greater than under the asset management approach, $x_{i}^{\prime}>x_{i}$. In this case, the home bias puzzle for pension plans is exacerbated. 
This model then suggests a null hypothesis: that DB plan home bias is partially explained by accounting for DB pension liabilities. This could arise in several ways. First, the covariance between domestic wage growth rate and international equity returns may be less than the covariance between domestic wage growth rate and domestic equity returns. If a domestic bull market lasted for several years, prosperity could boost the wage growth rate. Second, with respect to the discount assumption, the Financial Accounting Standard Rule 87 (FAS 87) requires the use of a so-called "settlement rate", i.e. the interest rate for which the DB pension obligation could be settled through the purchase of annuities. Many pension funds use the current yield on high-yield, long-term corporate bonds as an approximation. ${ }^{8}$ If the covariance between domestic bond returns and domestic stock returns is greater than that between domestic bonds and international equities, the second term of (9) could also be negative, consistent with more investment in domestic assets.

\section{Data and Empirical Results}

To assess how important these factors are in influencing DB plan portfolios, we conduct an empirical analysis taking the perspective of U.S. pension plan investors. First, to compare results with Lewis (1999), we suppose that our hypothetical pension plan can only invest in domestic equities and international equities. We then compare the asset allocations obtained when pension liabilities are ignored (as in the Lewis (1999) case) with those obtained when pension liabilities are taken into account. Next we add another asset class, namely U.S. bonds, and again compare resulting asset allocations. Last, we calculate and compare asset allocation when all equity returns and growth rates are real versus nominal.

The equity data are all taken from historical market indexes. To compare our results with Lewis (1999), the data include the period January 1970 to December $1996{ }^{9}$ The Morgan Stanley 
Capital International, Europe Australia, and Far East index (MSCI EAFE) in US dollars is used to calculate foreign equity returns, which include reinvested dividends. For U.S. equity returns, the paper uses the S\&P 500 total return index with dividends reinvested. The 10-year Treasury bond returns series are employed to approximate domestic bond market returns. Seasonally unadjusted average hourly earnings and weekly working hours of production workers are used to calculate the annual wage growth rate. ${ }^{10}$ For the discount rate, the paper uses year-end Moody's Aa corporate bond index. ${ }^{11}$ The Consumer Price Index (CPI) is employed to calculate the real equity and bond returns, as well as real wage growth rates and real discount rates. Descriptions of the nominal and real returns appear in Table $2 .^{12}$

\section{Table 2 here}

The second and third columns of Table 2 are for nominal returns. During the period January 1970 to December 1996, the mean return on nominal international investments was 15 percent, higher than the nominal domestic return of 13.6 percent, but the standard deviation of nominal international returns of 22.5 percent was also higher than for nominal domestic equity returns, of 16.2 percent. Therefore, compared to domestic equity returns, international equity had higher returns and higher volatility. ${ }^{13}$ The nominal average wage growth rate was positive at 4.7 percent, with a standard deviation of 2.2 percent. The average nominal discount rate was 9.6 percent with a standard deviation of 2.1 percent. The last two columns of Table 2 show descriptive statistics for real returns. Adjusted by inflation, the mean equity returns were smaller, but the standard deviations were larger, than their corresponding nominal counterparts. It is also worth to note that the real mean wage growth rate was negative at -0.78 , and its standard deviation was less than its nominal counterpart. 
Correlations between nominal equity returns, wage growth rates, and discount rates are shown in Panel A of Table 3. Contrary to our expectation of a positive correlation between wage growth rates and domestic equity returns, the actual correlation turned out to be negative at -0.25 . The main reason is that nominal wage growth rates were sticky, while equity returns were very volatile. These trends are reflected in Figure 1, where nominal wage growth rates changed slowly but domestic equity returns moved between -30 percent and +40 percent. Most of time, wage growth rates moved in the opposite direction from equity returns. The actual correlation between nominal international equity returns and wage growth rates was negative at -0.12 , smaller than that between domestic equity returns and wage growth rates. The correlation between nominal domestic equity returns and discount rates was positive, but small at 0.02 . The correlation between international equity returns and discount rates was -0.02 . The time pattern of domestic equity return and discount rate are provided in Figure 2. Compared with equity returns, the discount rate curve was rather smooth.

\section{Table 3, Figure 1, and Figure 2 here}

Correlations between real equity returns, wage growth rates, and discount rates, are reported in Panel B of Table 3. The correlation between real wage growth rates and domestic equities returns was positive at 0.35 , but the correlation between real wage growth rates and international equity returns was also large, at $0.42 .{ }^{14}$ One possible explanation is that the correlation between real domestic and international equity returns was very large, at 56 percent, in our data, so the correlations with wage growth rates were also similar. This pattern can be seen in Figure 3, where domestic and international equity returns show the similar time trend. Also in Figure 3, the real wage growth rates were more volatile and more positively correlated with equity returns than the nominal wage growth rates in Figure 1. The correlation between real 
domestic equity returns and the real discount rate, 0.48 , was larger than the correlation between real international equity returns and discount rate, 0.43. However the covariance between domestic equity returns and the discount rate, 0.0024 , was smaller than the covariance between international equity returns and the discount rate, 0.0030 , because the standard deviation of international equity returns was very high. The time pattern of real discount rates, nominal equity returns, and international equity returns appear in Figure 4. The real discount rates show more volatility than the nominal discount rate in Figure 2.

Figure 3 and Figure 4 here

Turning to the liability side, we model our hypothetical DB plan as having a funding ratio, or the ratio of assets to liabilities, of 100 percent. Going forward, the contribution rate is set at 10 percent of total payroll, the ratio of wage over pension asset is 20 percent, and the average tenure assumed for active participants is 15 years. ${ }^{15}$

In Table 4, short sales are permitted. Panel A of Table 4 reveals predicted DB plan asset allocations based on nominal equity returns, wage growth rates, and discount rates. Here we present calculated asset allocations from (2) and (7) using both the asset-only and the asset liability/approaches. As in Lewis (1995), we also find home bias in the investment portfolio, with projected international asset holdings of 23-56\% (under different level of risk aversion level $\lambda$ ) versus only $11.5 \%$ in $1996 .{ }^{16}$ Our results indicate that as risk aversion $\lambda$ rises, investors will hold more domestic equity and less foreign equity. This is consistent with previous studies, because international assets provide higher returns as well as higher risk. Incorporating DB plan liabilities in the asset allocation decision does not increase domestic holdings. On the contrary, it slightly increases international asset holdings, though the change is small (less than 1 percent) 
across the models. Therefore, incorporating the DB plan's liabilities does not explain pension plans' home bias.

Next, we extend the research by adding a third asset class, domestic bonds, which we would expect might better track actual pension portfolios. Similar to the two-asset case, we find that consideration of liabilities in asset allocation makes DB investors hold slightly more international assets, as compared with the asset-only approach. We also show, in the Panel A of Table 4, that pension plans are predicted to hold less foreign equities in three-asset case than they do in the two-asset case if there are no short sales of domestic bonds. However the changes are very small. For example, in the two-asset case and with a risk aversion level of 3 , the plan will hold 31.37 percent of its portfolios in international assets under the asset-only approach, and 31.75 percent under the asset/liability approach. These figures change to 29.41 and 29.79 respectively when domestic bonds are included as an investment option, resulting in a little more home bias than the two- asset class case.

\section{Table 4 here}

As we have shown, incorporating pension liabilities does little to explain DB plans' home bias in a model where all returns are nominal. Next we evaluate what happens if pension asset investments are allocated using real asset returns, real wage growth rates, and real discount rates. Panel B of Table 4 represents the asset allocations generated under the asset-only approach and the asset/liability approach using real returns. Including liabilities in the portfolio decision appears to imply that investors will invest a little less in domestic assets, but they will put more in international assets, as compared to the asset-only approach. This is because international equities do a better job of hedging wage changes and discount rate changes than do domestic equities. Consequently, the international investment proportion calculated from (7) is larger than 
the proportion calculated in (2). Extending the number of asset class from two to three again induces investors to invest less in international assets, as compared with the asset-only approach. To summarize, using real returns and taking liabilities into account further exacerbates DB pension plans' home bias puzzle.

In Table 5, short sales are restricted. If the asset proportion invested in domestic bond is negative, we set it to zero. Therefore, the asset proportion invested in international equity and domestic equity will be the same as the two asset class cases. We reach similar conclusions as in the case without short sales constraints as well.

\section{Table 5 here}

\section{Conclusions and Future Work}

This paper asks whether including DB pension liabilities in a model of pension asset allocation decision can help explain the well-known home bias. Taking the perspective of a US investor, we show that incorporating pension liabilities does not explain DB plan home bias when nominal returns are modeled. Furthermore, if instead we focus on real returns, incorporating plan liabilities makes the home bias puzzle worse. Consequently, we conclude that incorporating pension liabilities in the pension asset allocation decision cannot explain home bias in DB pension plans. Clearly, such pensions could stand to benefit from additional international investment.

We recognize that the results rely on several simplifying assumptions, which leaves room for extensions to this research. For example, one might explore other objective functions, a task we hope to undertake in future research. Additionally, this model assumes a representative agent whereas more detailed modeling could incorporate alternative demographic factors and their 
effects on pension asset allocation. Finally, this model does not evaluate hedging currency risk, which can be further explored in model extensions. 


\section{References}

Baxter, Marianne and Urban J. Jermann. 1997. "The International Diversification Puzzle is Worse Than You Think." American Economics Review 87(1): 170-180.

Cooper, Ian A. and Evi Kaplanis. 1994. "Home Bias in Equity Portfolios, Inflation Hedging, and International Capital Market Equilibrium.” Review of Financial Studies 7(1): 45-60.

Davis, E. Phillips. 2002. "Pension Fund Management and International Investment - A Global Perspective". Working paper presented at the Seminar Level Policy Seminar, Caribbean Center for Monetary Studies, Trinidad.

French, Kenneh R. and James M. Poterba. 1991. "Investor Diversification and International Equity Markets." The American Economic Review 81 (2):222-226.

Froot, Kenneth A., Paul G. O’Connell and Mark S. Seasholes. 2001. “The Portfolio Flows of International Investors.” Journal of Financial Economics 59(2): 151-193.

Froot, Kenneth A. and Tarun Ramadorai. 2001. "The Information Content of International Portfolio Flows." NBER working paper No.8472.

Grinold, Richard C. and Richard A. Meese. 2000. "Strategic Asset Allocation and International Investing." Journal of Portfolio Management 27(1)53-60.

Huberman, Gur. 2001. “Familiarity Breeds Investment.” Review of Financial Studies 14(3): 659-680.

Ibbotson, Roger G. and Rex A. Sinquefield. 1976. “Stocks, Bonds, Bills, and Inflation: Yearby-Year Historical Returns (1926-1974).” The Journal of Business 49(1): 11-47. 
Jacquillat, Bertrand and Bruno H. Solnik. 1978. "Multinationals are Poor Tools for Diversification." Journal of Portfolio Management 4 (2): 8-12.

Lewis, Karen. 1999. "Trying to Explain Home Bias in Equities and Consumption." Journal of Economics Literature 37: 571-608.

Lewis, Karen. 1995. "Puzzles in International Financial Markets." Handbook of International Economics, Elsevier Science B.V.:1913-1971.

Levy, Haim and Marshall Sarnat. 1970. "International Diversification of Investment Portfolios." American Economic Review 60(4): 668-675.

Moore, James and Michael Peskin. 2002. "Discount Benchmarks for Defined Benefit Pension Plans." Working paper.

Muralidhar, Arun S. 2001. Innovations in Pension Fund Management. Stanford, CA: Stanford University Press.

Seasholes, Mark S. 2000. “Smart Foreign Traders in Emerging Markets.” Working paper.

Sharpe, William F. and Lawrence G. Tint. 1990. "Liabilities—A New Approach.” Journal of Portfolio Management 16(2): 5-11.

Solnik, B. 1988. International Investments, Fourth Edition. Addison Wesley Longman, Inc.

Solnik, B. 1998. "Global Asset Management.” Journal of Portfolio Management 24(4): 43-51.

Tesar, Linda and Ingrid Werner. 1995. "Home Bias and High Turnover." Journal of International Money Finance 14(4): 467-492.

Winklevoss, Howard E. 1993. Pension Mathematics With Numerical Illustrations, Second Edition. Philadelphia: University of Pennsylvania Press, 1993. 
Table 1. Pension Fund Holdings of Foreign Investments (1980 to 1993)

Panel A: Holding of Foreign Securities by pension funds (1980 - 1993): percent of portfolio.

\begin{tabular}{|c|c|c|c|c|c|c|}
\hline & 1980 & 1988 & 1990 & 1991 & 1992 & 1993 \\
\hline Canada & 4.1 & 5.3 & 5.8 & 8.5 & 10.2 & 10.3 \\
\hline Germany & - & 3.8 & 4.5 & 4.5 & 4.3 & 4.5 \\
\hline Japan & 0.5 & 6.3 & 7.2 & 8.4 & 8.4 & 9.0 \\
\hline United Kingdom & 10.1 & 16.5 & 18.0 & 20.8 & 22 & 19.7 \\
\hline United States & 0.7 & 2.7 & 4.2 & 4.1 & 4.6 & 5.7 \\
\hline
\end{tabular}

Panel B: U.S Pension Funds' Holding of Foreign Investments (1994-1998): percent of portfolio.

\begin{tabular}{|l|c|c|c|c|c|}
\hline & 1994 & 1995 & 1996 & 1997 & 1998 \\
\hline U.S. Pension Funds & 10.4 & 10.4 & 11.5 & 12.3 & 11.8 \\
\hline
\end{tabular}

Source: Panel A from Lewis (1999). Panel B from Greenwich Associates, kindly provided by Richard Marston. Because of the different sources of data for Panel A and B, there may exist discrepancy for US pension fund.

Note: “_” means Not Available. 
Table 2. Description of Equity Returns, Wage Growth Rates, and Discount Rate (1970-1996)

\begin{tabular}{|l|r|r|r|r|}
\hline & \multicolumn{2}{|c|}{ Nominal } & \multicolumn{2}{|c|}{ Real } \\
\hline Variable & Mean & Std. Dev. & Mean & Std. Dev. \\
\hline $\begin{array}{l}\text { Foreign equity } \\
\text { return(Ri) }\end{array}$ & 15.00 & 22.52 & 9.29 & 22.86 \\
\hline $\begin{array}{l}\text { Domestic equity return } \\
(\mathrm{Rd})\end{array}$ & 13.56 & 16.20 & 7.86 & 16.54 \\
\hline $\begin{array}{l}\text { Domestic bond return } \\
(\mathrm{Rb})\end{array}$ & 9.91 & 10.23 & 4.36 & 11.34 \\
\hline Wage growth rate (Rw) & 4.73 & 2.22 & -0.78 & 2.42 \\
\hline Discount rate (r) & 9.57 & 2.12 & 4.05 & 3.11 \\
\hline $\begin{array}{l}\text { Product of wage growth } \\
\text { and discount rate (rRw) }\end{array}$ & 0.47 & 0.28 & 0.01 & 0.08 \\
\hline
\end{tabular}

Notes: MSCI EAFE total return index used for foreign equity returns. S\&P 500 total return index used for domestic equity returns. 10-year treasury bond return used for domestic bond returns. All monthly data are annualized. The data of MSCI EAFE are from Datastream. S\&P500 and 10 year treasury bond are from CRSP. Seasonally unadjusted average hourly earnings of production workers used for the annual wage growth rate. The average of Moody's Aa corporate bond index is used for the discount rate. Data on average hourly earnings and weekly working hours of production workers are from the web site of Bureau of Labor Statistics, http://www.bls.gov. Moody's Aa corporate bond index data are from Bloomberg. Consumer Price Index (CPI) is employed to calculate the real equity and bond returns, as well as real wage growth rates and real discount rates. 
Table 3. Correlations Between Equity Returns, Wage Growth Rates, and Discount Rates (19701996)

Panel A. Nominal returns

\begin{tabular}{|l|r|r|r|r|r|r|}
\hline & $\mathrm{Ri}$ & $\mathrm{Rd}$ & $\mathrm{Rb}$ & $\mathrm{RW}$ & $\mathrm{R}$ & $\mathrm{rRw}$ \\
\hline Foreign equity return(Ri) & 1.00 & & & & & \\
\hline $\begin{array}{l}\text { Domestic equity return } \\
(\mathrm{Rd})\end{array}$ & 0.51 & 1.00 & & & & \\
\hline $\begin{array}{l}\text { Domestic bond return } \\
(\mathrm{Rb})\end{array}$ & 0.08 & 0.41 & 1.00 & & & \\
\hline Wage growth rate (Rw) & -0.12 & -0.25 & -0.35 & 1.00 & & \\
\hline Discount rate (r) & -0.02 & 0.02 & $\begin{array}{r}-7.0 \mathrm{e}- \\
04\end{array}$ & 0.30 & 1.00 & \\
\hline $\begin{array}{l}\text { Product of wage growth } \\
\text { and discount rate (rRw) }\end{array}$ & -0.13 & -0.18 & -0.28 & 0.88 & 0.68 & 1.00 \\
\hline
\end{tabular}

Panel B. Real returns

\begin{tabular}{|l|r|r|r|r|r|r|}
\hline & $\mathrm{Ri}$ & $\mathrm{Rd}$ & $\mathrm{Rb}$ & $\mathrm{Rw}$ & $\mathrm{R}$ & $\mathrm{rRw}$ \\
\hline Foreign equity return(Ri) & 1.00 & & & & & \\
\hline $\begin{array}{l}\text { Domestic equity return } \\
(\mathrm{Rd})\end{array}$ & 0.56 & 1.00 & & & & \\
\hline $\begin{array}{l}\text { Domestic bond return } \\
(\mathrm{Rb})\end{array}$ & 0.24 & 0.53 & 1.00 & & & \\
\hline Wage growth rate (Rw) & 0.42 & 0.35 & 0.34 & 1.00 & & \\
\hline Discount rate (r) & 0.43 & 0.48 & 0.54 & 0.59 & 1.00 & \\
\hline $\begin{array}{l}\text { Product of wage growth } \\
\text { and discount rate (rRw) }\end{array}$ & -0.05 & -0.19 & -0.05 & 0.27 & -0.20 & 1.00 \\
\hline
\end{tabular}

Note: Author's tabulations from data described in Table 2. 
Table 4. Optimal Asset Allocations for U.S. Pension Plans (Short Sales Permitted) Panel A. Nominal Returns

\begin{tabular}{|c|c|c|c|c|c|c|}
\hline & Model & Asset class & $\lambda=1$ & $\lambda=2$ & $\lambda=3$ & $\lambda=10$ \\
\hline \multirow{3}{*}{ Two asset class } & Asset-only & $\begin{array}{l}\text { Foreign equity } \\
\text { Domestic equity }\end{array}$ & $\begin{array}{l}55.52 \\
44.48 \\
\end{array}$ & $\begin{array}{l}37.41 \\
62.59\end{array}$ & $\begin{array}{l}31.37 \\
68.63\end{array}$ & $\begin{array}{l}22.92 \\
77.08\end{array}$ \\
\hline & \multirow{2}{*}{ Asset/Liability } & Foreign equity & 55.89 & 37.78 & 31.75 & 23.3 \\
\hline & & Domestic equity & 44.11 & 62.22 & 68.25 & 76.7 \\
\hline \multirow{6}{*}{ Three asset class } & \multirow{3}{*}{ Asset-only } & Foreign equity & 61.19 & 37.35 & 29.41 & 18.28 \\
\hline & & Domestic equity & 119.66 & 61.85 & 42.58 & 15.61 \\
\hline & & Domestic Bond & -80.85 & 0.8 & 28.01 & 66.11 \\
\hline & \multirow{3}{*}{ Asset/Liability } & Foreign equity & 61.57 & 37.73 & 29.79 & 18.55 \\
\hline & & Domestic equity & 119.37 & 61.56 & 42.29 & 15.31 \\
\hline & & Domestic Bond & -80.94 & 0.71 & 27.92 & 66.14 \\
\hline
\end{tabular}

Panel B. Real Returns

\begin{tabular}{|c|c|c|c|c|c|c|}
\hline \multirow{3}{*}{ Two asset class } & Asset-only & $\begin{array}{l}\text { Foreign equity } \\
\text { Domestic equity }\end{array}$ & $\begin{array}{l}55.05 \\
44.95 \\
\end{array}$ & $\begin{array}{l}35.8 \\
64.2 \\
\end{array}$ & $\begin{array}{l}29.39 \\
70.61 \\
\end{array}$ & $\begin{array}{l}20.4 \\
79.6 \\
\end{array}$ \\
\hline & \multirow{2}{*}{ Asset/Liability } & Foreign equity & 59.35 & 40.01 & 33.68 & 24.7 \\
\hline & & Domestic equity & 40.65 & 59.99 & 66.32 & 75.3 \\
\hline \multirow{5}{*}{ Three asset class } & \multirow[t]{2}{*}{ Asset-only } & $\begin{array}{l}\text { Foreign equity } \\
\text { Domestic equity }\end{array}$ & $\begin{array}{c}61.21 \\
133.56\end{array}$ & $\begin{array}{l}36.13 \\
68.97\end{array}$ & $\begin{array}{l}27.78 \\
47.44\end{array}$ & $\begin{array}{r}16.07 \\
17.3\end{array}$ \\
\hline & & Domestic Bond & -94.77 & -5.1 & 24.78 & 66.63 \\
\hline & \multirow{3}{*}{ Asset/Liability } & Foreign equity & 65.89 & 40.81 & 32.45 & 20.75 \\
\hline & & Domestic equity & 134.8 & 70.22 & 48.69 & 18.55 \\
\hline & & Domestic Bond & -100.69 & -11.03 & 18.86 & 60.7 \\
\hline
\end{tabular}

Source: Author's tabulation

Notes:

Two asset class includes domestic and international equities. Three asset class includes international stocks, domestic stocks and domestic bonds. In this table, there are no short sales constrictions. The asset proportions could be negative. 
Table 5. Optimal Asset Allocations for U.S. Pension Plans (Short Sales Restricted)

Panel A. Nominal Returns

\begin{tabular}{|l|c|ccccc|}
\hline \multirow{5}{*}{ Two asset class } & Model & Asset class & $\lambda=1$ & $\lambda=2$ & $\lambda=3$ & $\lambda=10$ \\
\hline \multirow{5}{*}{ Three asset class } & \multirow{2}{*}{ Asset-only } & Foreign equity & 55.52 & 37.41 & 31.37 & 22.92 \\
& & Domestic equity & 44.48 & 62.59 & 68.63 & 77.08 \\
\cline { 2 - 7 } & \multirow{4}{*}{ Asset/Liability } & Foreign equity & 55.89 & 37.78 & 31.75 & 23.3 \\
& & Domestic equity & 44.11 & 62.22 & 68.25 & 76.7 \\
\cline { 3 - 7 } & \multirow{4}{*}{ Asset-only } & Foreign equity & 55.52 & 37.35 & 29.41 & 18.28 \\
& & Domestic equity & 44.48 & 61.85 & 42.58 & 15.61 \\
& \multirow{4}{*}{ Asset/Liability } & Domestic Bond & 0 & 0.8 & 28.01 & 66.11 \\
& & Foreign equity & 55.89 & 37.73 & 29.79 & 18.55 \\
& & Domestic equity & 44.11 & 61.56 & 42.29 & 15.31 \\
& & Domestic Bond & 0 & 0.71 & 27.92 & 66.14 \\
\hline
\end{tabular}

Panel B. Real Returns

\begin{tabular}{|c|c|c|c|c|c|c|}
\hline \multirow{4}{*}{ Two asset class } & \multirow{2}{*}{ Asset-only } & Foreign equity & 55.05 & 35.8 & 29.39 & 20.4 \\
\hline & & Domestic equity & 44.95 & 64.2 & 70.61 & 79.6 \\
\hline & \multirow{2}{*}{ Asset/Liability } & Foreign equity & 59.35 & 40.01 & 33.68 & 24.7 \\
\hline & & Domestic equity & 40.65 & 59.99 & 66.32 & 75.3 \\
\hline \multirow{6}{*}{ Three asset class } & \multirow{3}{*}{ Asset-only } & Foreign equity & 55.05 & 35.8 & 27.78 & 16.07 \\
\hline & & Domestic equity & 44.95 & 64.2 & 47.44 & 17.3 \\
\hline & & Domestic Bond & 0 & 0 & 24.78 & 66.63 \\
\hline & \multirow{3}{*}{ Asset/Liability } & Foreign equity & 59.35 & 40.01 & 32.45 & 20.75 \\
\hline & & Domestic equity & 40.65 & 59.99 & 48.69 & 18.55 \\
\hline & & Domestic Bond & 0 & 0 & 18.86 & 60.7 \\
\hline
\end{tabular}

Source: Author's tabulations

Notes: Two asset class includes domestic and international equities. Three asset class includes international stocks, domestic stocks and domestic bonds. In this table, short sales are restricted. If the asset proportion invested in domestic bond is negative, we set it to zero. Therefore, the asset proportion invested in international equity and domestic equity will be the same as the two asset class cases. 


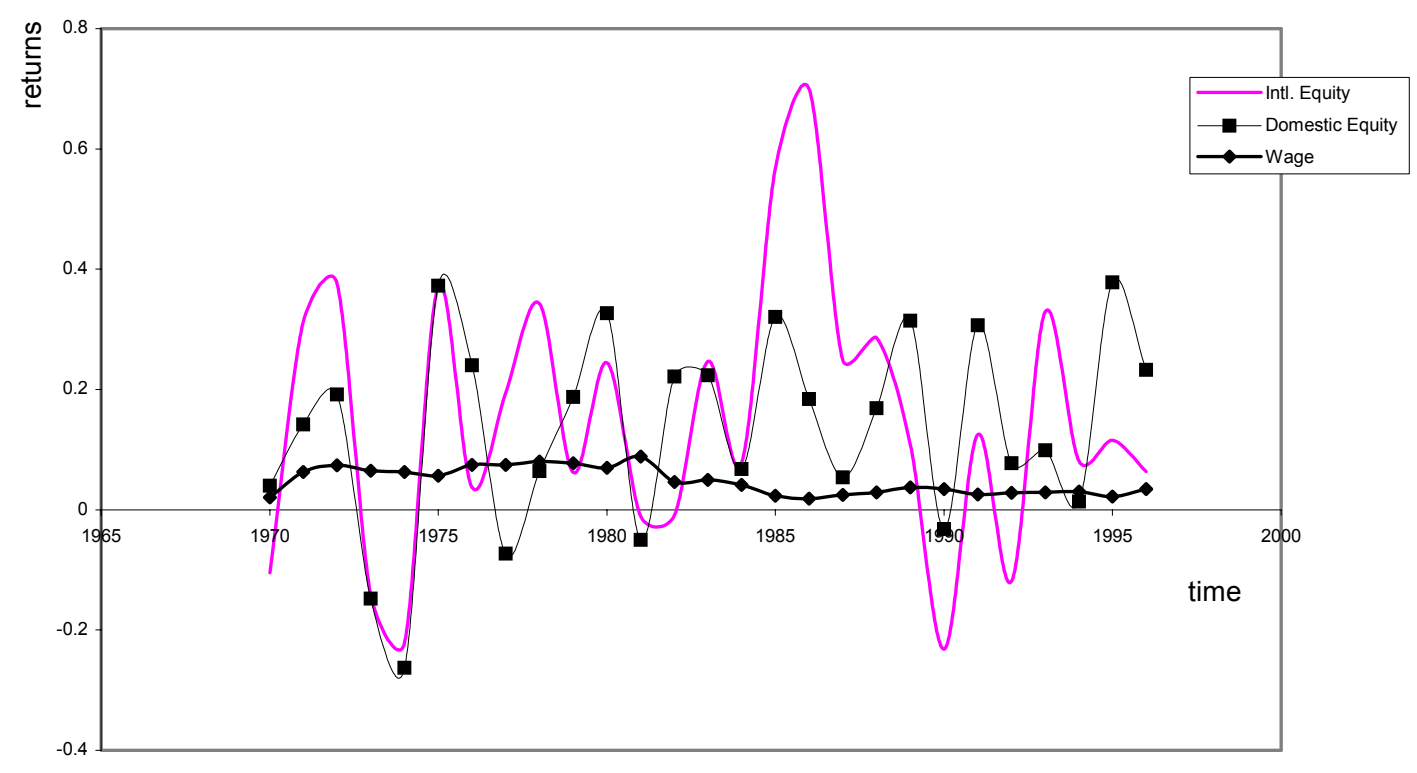

Figure 1. Time Pattern of Nominal Wage Growth Rates, Domestic Equity Returns, and International Equity Returns.

Source: From data described in Table 2.

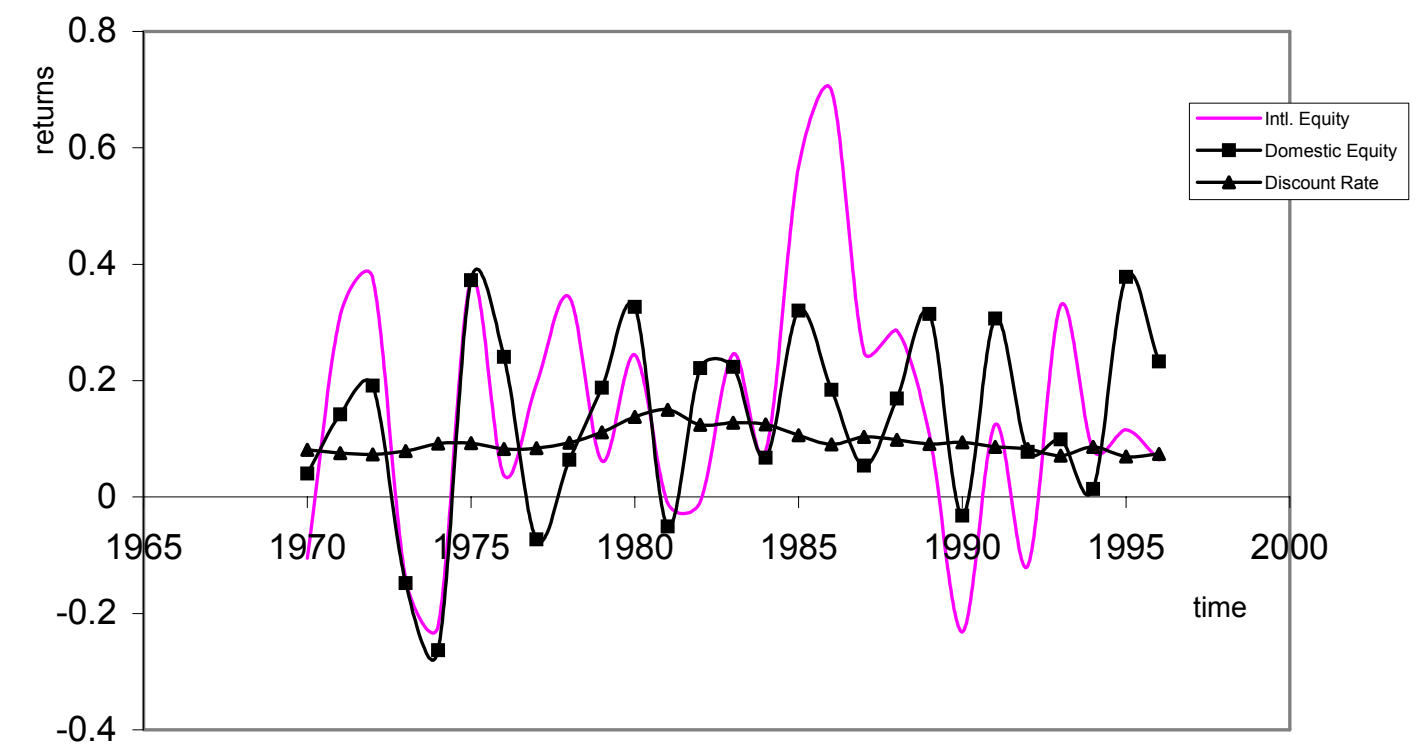

Figure 2. Time Pattern of Nominal Discount Rates, Domestic Equity Returns, and International Equity Returns.

Source: From data described in Table 2. 


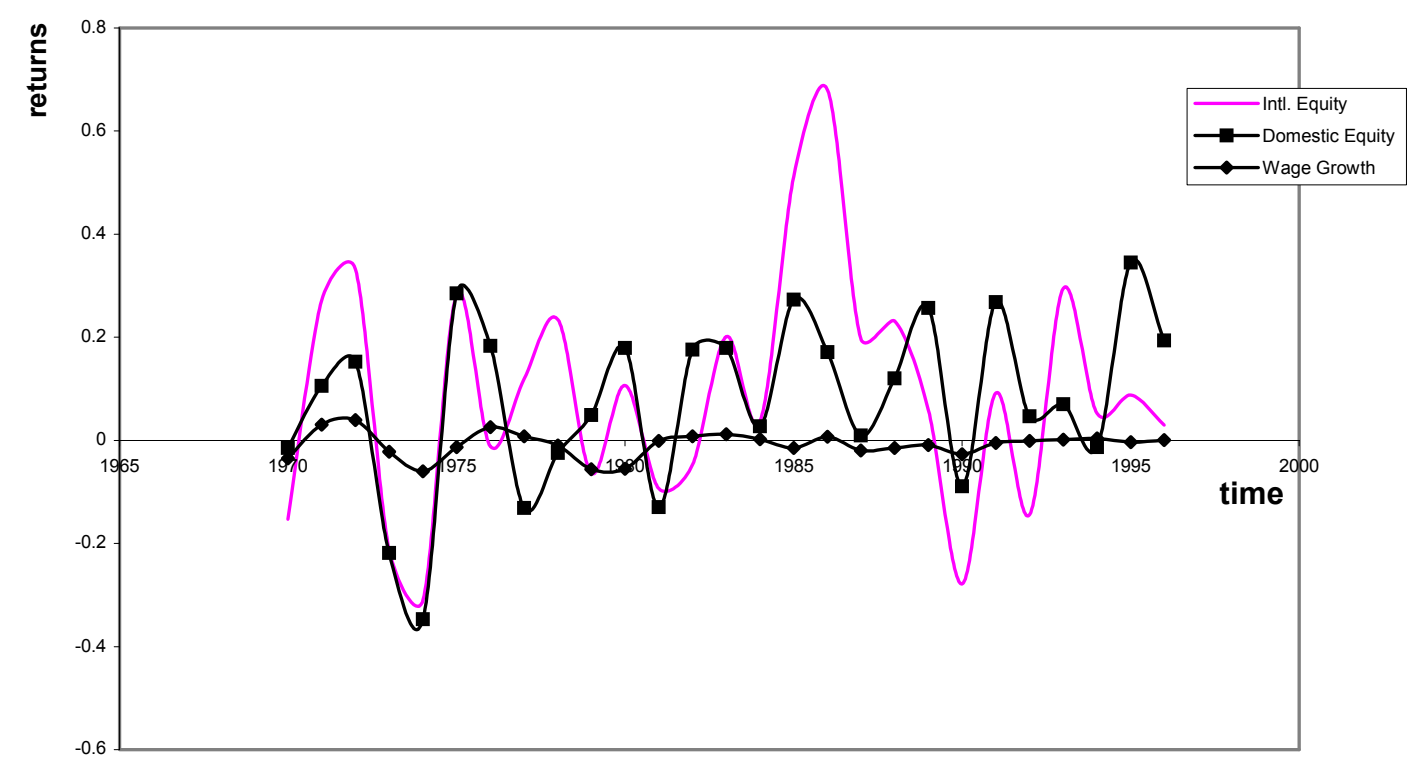

Figure 3. Time Pattern of Real Wage Growth Rates, Domestic Equity Returns, and International Equity Returns

Source: From data described in Table 2.

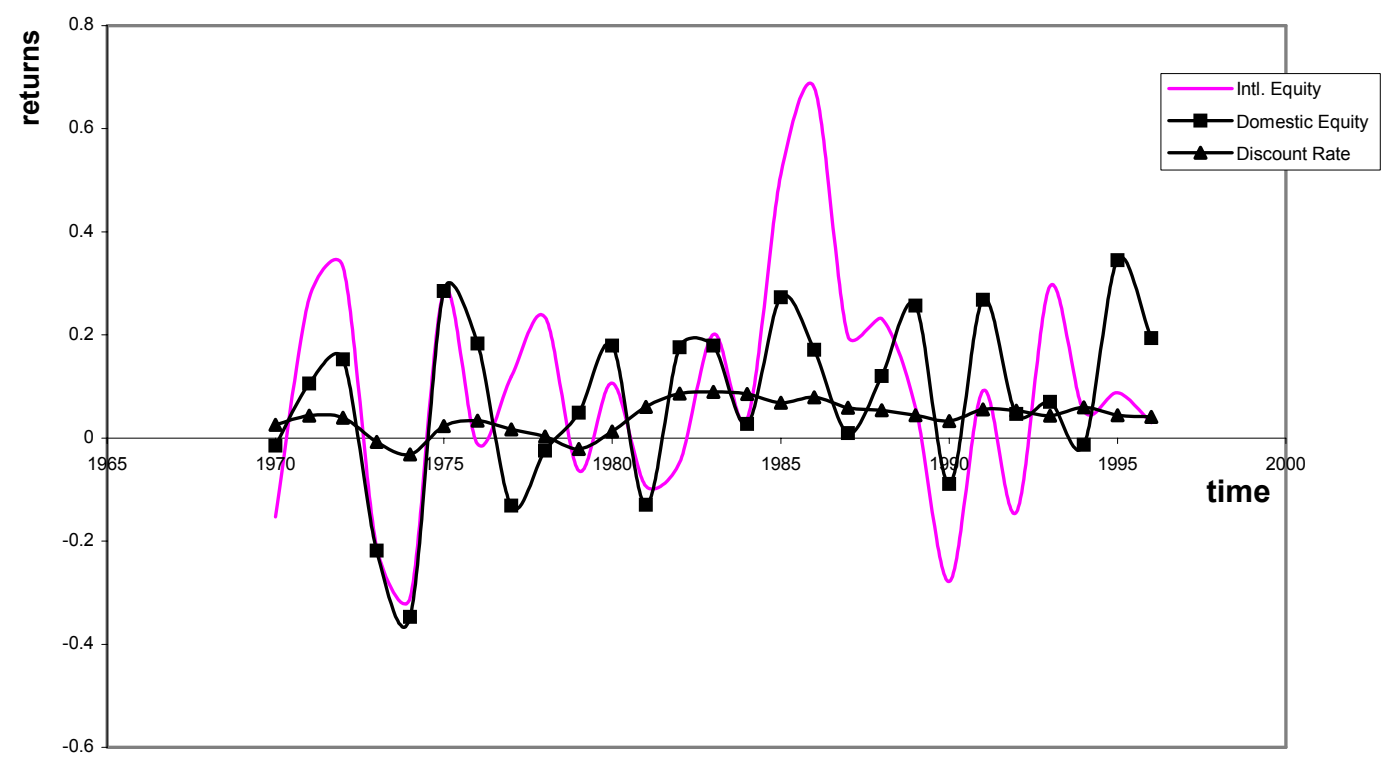

Figure 4. Time Pattern of Real Discount Rates, Domestic Equity Returns, and International Equity Returns.

Source: From data described in Table 2. 


\section{Appendix 1. The derivation of maximization problem (5)}

The maximization problem (3) is the following problem

$$
\underset{\mathrm{x}_{\mathrm{d}}, \mathrm{x}_{\mathrm{i}}}{\operatorname{Max}} E\left(\frac{\widetilde{S}_{1}}{A_{0}}\right)-\lambda \operatorname{Var}\left(\frac{\widetilde{S}_{1}}{A_{0}}\right)
$$

and

$$
\begin{aligned}
\frac{\widetilde{S}_{1}}{A_{0}} & =\left(1+\widetilde{R}_{A}\right)+m \frac{W_{0}}{A_{0}} \frac{\widetilde{W}_{1}}{W_{0}}-\frac{L_{0}}{A_{0}} \frac{\widetilde{L}_{1}}{L_{0}} \\
& =\left(1+\widetilde{R}_{A}\right)+m \frac{W_{0}}{A_{0}}\left(1+\widetilde{R}_{W}\right)-\frac{L_{0}}{A_{0}}\left(1+\widetilde{R}_{L}\right) \\
& =\left(1+m \frac{W_{0}}{A_{0}}-\frac{L_{0}}{A_{0}}\right)+\left(\widetilde{R}_{A}+m \frac{W_{0}}{A_{0}} \widetilde{R}_{W}-\frac{L_{0}}{A_{0}} \widetilde{R}_{L}\right)
\end{aligned}
$$

where $\widetilde{R}_{W}$ and $\widetilde{R}_{L}$ are the growth rate of wage and liability. The first bracketed expression involves no uncertainty, so asset allocation decisions cannot affect it. For purpose of decisionmaking, one can concentrate entirely on the second expression.

Let

$$
\widetilde{Z}=\widetilde{R}_{A}+m \frac{W_{0}}{A_{0}} \widetilde{R}_{W}-\frac{L_{0}}{A_{0}} \widetilde{R}_{L},
$$

(A.1) will equal to

$$
\underset{x_{d}, x_{i}}{\operatorname{Max}} E(\widetilde{Z})-\lambda \operatorname{Var}(\widetilde{Z})
$$

where

$$
\begin{aligned}
\operatorname{Var}(\widetilde{Z}) & =\operatorname{Var}\left[\widetilde{R}_{A}+m \frac{W_{0}}{A_{0}} \widetilde{R}_{W}-\frac{L_{0}}{A_{0}} \widetilde{R}_{L}\right] \\
& =\operatorname{Var}\left(\widetilde{R}_{A}\right)+\left(m \frac{W_{0}}{A_{0}}\right)^{2} \operatorname{Var}\left(\widetilde{R}_{W}\right)+\left(\frac{L_{0}}{A_{0}}\right)^{2} \operatorname{Var}\left(\widetilde{R}_{L}\right) \\
& +2 m \frac{W_{0}}{A_{0}} \operatorname{cov}\left(\widetilde{R}_{A}, \widetilde{R}_{W}\right)-2 \frac{L_{0}}{A_{0}} \operatorname{cov}\left(\widetilde{R}_{A}, \widetilde{R}_{L}\right)-2 m \frac{W_{0} L_{0}}{A_{0}{ }^{2}} \operatorname{cov}\left(\widetilde{R}_{W}, \widetilde{R}_{L}\right) .
\end{aligned}
$$

Since our decision variable is asset allocation proportion, $x_{i}$ and $x_{d}$, we can ignore the terms not affected by asset allocation, such as the second, third and last term, without affecting the final result. Then the maximization problem is simplified to

$$
\underset{x_{d}, x_{i}}{\operatorname{Max}} E\left(\widetilde{R}_{A}\right)-\frac{\lambda}{2} \operatorname{Var}\left(\widetilde{R}_{A}\right)-\lambda m \frac{W_{0}}{A_{0}} \operatorname{cov}\left(\widetilde{R}_{A}, \widetilde{R}_{W}\right)+\lambda \frac{L_{0}}{A_{0}} \operatorname{cov}\left(\widetilde{R}_{A}, \widetilde{R}_{L}\right)
$$




\section{Appendix 2. Variable Definitions}

Note: for subscript $\mathrm{i}, \mathrm{i}=1$ means next year, and $\mathrm{i}=0$ means today.

$\begin{array}{ll}\widetilde{A}_{i} & \text { DB plan asset at time i. } \\ \widetilde{B} & \text { Final pay pension benefit. } \widetilde{B}=k^{*} \widetilde{W}^{*} T . \\ B_{r} & \text { Average benefit payment, constant. } \\ \widetilde{C} & \text { Total contribution of the pension plan is a certain percentage. } \\ E(B)_{1} & \text { Yearly expected benefit payments. } \\ h & \text { Fraction of ABO to account for service and salary increase. } \\ k & \text { A constant factor of final pay. } \\ \widetilde{L}_{i} & \text { DB plan liability at time i. } \\ m & \text { Pension plan contribution rate, as a constant proportion of payroll of wage. } \\ r & \text { Discount rate used with ABO. } \\ \widetilde{R}_{A} & \text { Total portfolio return. } \\ \widetilde{R}_{d} & \text { Actual return on domestic assets. } \\ \widetilde{R}_{i} & \text { Actual return on international assets. } \\ \widetilde{R}_{L} & \text { Liability growth rate. } \\ \widetilde{R}_{W} & \text { Wage growth rate. } \\ \widetilde{S}_{i} & \text { DB plan's surplus in year i. } \widetilde{S}_{i}=\widetilde{A}_{i}-\widetilde{L}_{i} . \\ T_{i} & \text { Year of service at time i. } \\ \bar{T}_{0} & \text { Average years of service of active plan participants as of today, constant. } \\ U_{i} & \text { Liability-adjusted expected return on international equity. } \\ U_{d} & \text { Liability-adjusted expected return on domestic equity } \\ \widetilde{W} & \text { The wage of plan participants at year i. } \\ x_{d} & \text { Proportion of total assets invested in domestic equities. } \\ x_{i} & \text { Proportion of total assets invested in international equities. } \\ \mu_{d}, \sigma_{d} & \text { Expected return and standard deviation on domestic equity returns. } \\ \mu_{i}, \sigma_{i} & \text { Expected return and standard deviation on international equity returns. } \\ \sigma_{d i} & \text { Covariance between domestic and international equity returns. } \\ \lambda & \text { Risk aversion of institutional investors. } \\ & \end{array}$




\section{Endnotes}

${ }^{1}$ See details in Lewis (1999).

${ }^{2}$ Tesar and Ingrid Werner (1995) show that home bias appears in bonds as well as equity, further deepening the home bias puzzle. Here, we focus on the equity market, and below we include bonds to see if the empirical results differ.

${ }^{3}$ More detailed discussion of pension fund investment objectives see Muralidhar (2001).

${ }^{4}$ This supposes no amortizations of unfunded liabilities from previous years.

${ }^{5}$ The accumulated Benefit Obligation (ABO) and the Projected Benefit Obligation (PBO) are defined under the Financial Accounting Standard 87 (FAS 87), where the primary objective is to achieve consistency, uniformity, and comparability with respect to pension plan accounting among plan sponsors. See details in Winklevoss (1993).

${ }^{6}$ This approximation is from Chapter 11, Winklevoss (1993). The original formula is

$$
(A B O)_{t+1} \approx\left[(A B O)_{t}+h(A B O)_{t}\right](1+i)-E(B)_{t}(1+1 / 2 i)
$$

The fractional coefficient in the last term is intended to represent a weighted average of monthly benefit payments throughout the year. But for simplicity in this paper, we assume pension benefit payment is made only once a year. Therefore, this term is changed to $E(B)_{1}$ instead.

${ }^{7}$ Most of the time $\lambda\left[\frac{L_{0}}{A_{0}}\left(1+\frac{1}{\bar{T}}\right)-m \frac{W_{0}}{A_{0}}\right]>0$, because for a pension plan with several years of history and a good funding status, total liabilities $L_{0}$ should be greater than annual contributions $m W_{0}$

${ }^{8}$ See details in Winklevoss (1993).

${ }^{9}$ In an unreported simulation, we calculate the optimal asset allocation using the data from December 1929 to December 2001. Our main results do not change with the new data period. However, the international index is "GFD World x/USA \$ Return Index" from Global Financial 
Data, Inc., instead of MSCI EAFE index used in the paper because EAFE is only available since December 1969.

${ }^{10}$ Average hourly earnings and weekly working hours of production workers are from the web site of the U.S. Bureau of Labor Statistics, http://www.bls.gov.

11 Moore and Peskin (2002) show that the end of year Moody's Aa index tracks the average FAS 87 discount rates closely.

12 MSCI EAFE data are from Datastream. S\&P500, 10 year treasury bond and CPI data are drawn from CRSP. We annualized monthly data first to calculate annual asset allocations. See Ibbotson and Sinquefield (1976) for detailed annualizing method.

${ }^{13}$ Our mean and variances for the EAFE and S\&P 500 indices differ from those reported by Lewis (1999), because we use different methods to compute descriptive statistics. We compounded the monthly returns to get annual returns, and then calculated the variance of annual returns. But Lewis (1999) calculated the arithmetic mean and variance-covariance matrix of monthly data, then annualized these mean and variance by multiplying 12 .

14 This pattern is similar to Baxter and Jermann (1997) who examined the correlations between labor growth and capital growth rates over 1960 -1993. They found that the correlation between U.S earnings growth rate and U.S. capital growth rate was 0.54 , while the correlation between U.S. earnings growth and capital growth rates in Japan, Germany and the U.K. were 0.55, 0.47 and 0.48 respectively. Their measure of labor income is total employee compensation; their measure of capital income is GDP at factor cost minus employee compensation.

${ }^{15}$ We have also varied these parameters to investigate the robustness of results, but we find little sensitivity. For example, when the funding ratio is valued between 50 and 200 percent, the implied international investment proportion changes by only 1 percent. 
${ }^{16}$ These projected asset allocations under the two asset class model differ from those in Lewis (1995) because the methodologies of annualizing data are different. 